\title{
Chemical properties of an Oxisol under organic management as influenced by application of sugarcane bagasse $\operatorname{ash}^{1}$
}

\author{
Propriedades químicas de um Latossolo sob manejo orgânico influenciado pela \\ aplicação de cinzas de bagaço de cana
}

\author{
Enderson Petrônio de Brito Ferreira ${ }^{2 *}$, Nand Kumar Fageria ${ }^{2}$ e Agostinho Dirceu Didonet ${ }^{2}$
}

\begin{abstract}
There are large areas of Oxisols in South America, including Brazil, with low fertility and acidity. To improve crop yields on these Oxisols, liming and fertilization is an essential practice. However, besides the high cost of fertilizers, chemical fertilizers cannot be used in organic production systems, except insoluble sources. Ash is one of the alternative source of supplying macro and micronutrients. A field experiment was conducted, in a completely randomized block design in a factorial arrangement (three sources of ash $\mathrm{x}$ four rates) resulting on 12 treatments, to evaluate the effect of source and rate of ash application on soil chemical properties. The treatments consisted of three sources (bagasse, bagasse+PJ07-A and bagasse+PJ07-RA) of sugarcane ash applied in four rates as $0 ; 5 ; 15$ and $30 \mathrm{Mg} \mathrm{ha}^{-1}$. Results showed that the use of ash significantly improved soil chemical properties such as $\mathrm{pH}, \mathrm{P}, \mathrm{K}, \mathrm{Mg}$, base saturation, $\mathrm{K}$ and $\mathrm{Mg}$ saturation and significantly reduced soil acidity $(\mathrm{H}+\mathrm{Al})$. Depending on the ash source or rate, some of the soil chemical properties were affected, however, the effect of ash source was not so pronounced as compared with ash rate. Ashes application resulted on a soil nutritional condiction enough to guarantee the growth and yield of most annual crops. Ash sources were equally effective in reducing acidity and improving soil fertility under this study condition, while increasing ash rate provides decrease in $\mathrm{H}+\mathrm{Al}$ content and increase in $\mathrm{pH}, \mathrm{Mg}, \mathrm{P}$ and $\mathrm{K}$.
\end{abstract}

Key words - Base saturation. Organic residue. Alternative fertilizer.

\begin{abstract}
Resumo - Existem extensas áreas de Latossolo na América do Sul com baixa fertilidade e acidez, inclusive no Brasil. Para melhorar a produtividade desses solos, o uso de fertilizantes e calcário é uma prática essencial. Contudo, além dos altos custos destes insumos, seu uso não é permitido em sistemas de produção orgânica. Dependendo da fonte, as cinzas podem fornecer macro e micronutrientes para culturas anuais. Foi conduzido um experimento de campo, em delineamento de blocos ao acaso com arranjo fatorial (três fontes de cinza x quatro doses) resultando em 12 tratamentos, para avaliar o efeito do tipo e de doses de cinzas nas propriedades químicas do solo. Os tratamentos consistiram de três tipos de cinzas e quatro doses $0 ; 5 ; 15$ e $30 \mathrm{Mg} \mathrm{ha}^{-1}$. Os resultados indicaram que o uso de cinzas melhorou significativamente algumas propriedades químicas do solo, como: $\mathrm{pH}, \mathrm{K}, \mathrm{Mg}$, saturação de bases, saturação por $\mathrm{K}$ e $\mathrm{Mg}$ e reduziu significativamente a acidez total $(\mathrm{H}+\mathrm{Al})$. Dependendo do tipo de cinza usado, algumas das propriedas químicas do solo foram afetadas, contudo, o efeito do tipo não foi tão marcante quanto o efeito da dose. A aplicação das cinzas resultou em uma condição nutricional do solo adequadas para o crescimento e produção da maioria das culturas anuais. Os três tipos de cinzas foram igualmente eficientes em reduzir a acidez e melhorar a fertilidade do Latossolo de Cerrado, enquanto que um aumento na dose aplicada provocou diminuição do teor de $\mathrm{H}+\mathrm{Al}$ e aumento nos teores de $\mathrm{pH}, \mathrm{Mg}, \mathrm{P}$ and $\mathrm{K}$.
\end{abstract}

Palavras-chave - Saturação de bases. Resíduos orgânicos. Fertilizante alternativo.

\footnotetext{
*Autor para correspondência

'Recebido para correspondência em 27/10/2010; aprovado em 09/11/2011

Trabalho realizado com recursos do convênio INCRA/FAPED/EMBRAPA

2Embrapa Arroz e Feijão, Santo Antônio de Goiás-GO, Brasil, 75.375-000, enderson@ cnpaf.embrapa.br, fageria@cnpaf.embrapa.br, didonet@cnpaf.embrapa.br
} 


\section{Introduction}

Brazil is the largest sugarcane producing country in the world with a harvested area of 8,598,440 ha, and sugarcane production about 690 million ton on 2009 (FAO, 2010), used for sugar and alcohol production, generating about 100 millions of tons of sugarcane bagasse as residue. Similarly, Brazil is the largest world cattle producer with about 204 million heads, representing $17 \%$ of the world cattle production on 2009 (FAO, 2010). Sugarcane as well as cattle production and meat processing generates great amounts of organic residues, such as sugarcane bagasse, filter cake, stillage, tallow, fat, blood and bones which show great environmental problems related to its disposal. However, virtually all industrial sugarcane and meat processing residues are potencially reused.

Sugarcane bagasse can be used for animal feed (SELMAN-HOUSEIN et al., 2000) or for the generation of energy (ALONSO-PIPPO et al., 2008; MIRZA et al., 2008) through bagasse burning resulting in great amounts of ash, which are frequently disposed without treatment on the environment. The same problem is observed for organic residues of meat processing. Besides the environmental contamination, the non-use of these residues implies on natural resources wasting.

Therefore, the burning of sugarcane bagasse amended with organic residues of meat processing could result in ashes with elevated levels of some nutrients, such as calcium, potassium and phosphorus, leading to improve the production system sustainability. Notwithstanding, research studies involved on this subject are still scarce.

Depending on the material of origin, ash can provide significant amounts of macro and micronutrients, and may be used to replace mineral fertilization and liming, depending on the soil nutritional balance and the crop needs according to its productivity level (LEE et al., 2006; SALEQUE et al., 2004). For example, rice husk ash, a huge by-product from rice milling, may also be applied to rice fields to supply $\mathrm{K}, \mathrm{Ca}, \mathrm{Mg}$ and other minerals (HASHIM et al., 1996), while fly ash from coal combustion is a glassy material with a very high available Si content (ADRIANO et al., 1980).

Although soils have an inherent quality as related with their physical, chemical and biological properties, land management plays an important role on the soil quality (DORAN, 2002). Thus, organic production systems are indicated to be used due to the low external inputs, and soil management practices are employed aiming to minimize deleterious effects on the environment. According to Oquist et al. (2007), alternative agricultural practices, such as soils cropped under organic systems have also been described as environmentally beneficial.
Therefore, the use of ash in cropping systems, including organic systems may allow to improve soil chemical properties (PERUCCI et al., 2008; SAARSALMI et al., 2006), and contribute to increase the yield (MOYINJESU, 2007; SAARSALMI et al., 2006;). Studies suggest that ashes are high in nutrient contents and had been used as a soil amendment (ADRIANO et al., 1980) without any adverse effects on soil and crop (SELL et al., 1989), consisting an alternative to substitute part of the fertilizer requirements (GÓRECKA et al., 2006).

However, nutrient contents in ashes may vary according to its origin material. Thus, the objective of this study was to determine changes in soil chemical properties as a result of different ashes sources and rates application.

\section{Material and methods}

The experiment was conducted on an Integrated System for Agroecological Production at the Empresa Brasileira de Pesquisa Agropecuária - EMBRAPA National Rice and Beans Research Center, Capivara farm, Santo Antônio de Goiás county, state of Goiás, in the central part of Brazil (latitude 16²9'40" S, longitude $49^{\circ} 17^{\prime} 30^{\prime \prime} \mathrm{W}$ and $823 \mathrm{~m}$ above sea level). According to the Köppen classification, the local climate is classified as Aw, tropical savanna, megathermic. The rainfall regime is well defined, with the rainy and dry seasons from October to April and from May to September, respectively, with annual rainfall mean of $1460 \mathrm{~mm}$ (SILVA et al., 2002). The soil of the experimental area was an Oxisol, cultivated under organic production system, in which soil was maintained since 2003 under leguminous cover crops (Crotalaria juncea, Mucuna aterrina, Cajanus cajan and Canavalia ensiformis) followed by rice (Oriza sativa) and common bean (Phaseolus vulgaris) to compose the used cropping rotation system on each agricultural season. The chemical and physical properties of the soil before experiment installation are presented in Table 1.

The experiment was carried out in the period comprising the summer season. Ashes were mixed into soil on 29 October 2007 and rice was cultivated from November 2007 to February 2008, when climate conditions were relatively constant over the entire plant growth period (TAB. 2).

The experimental designused consisted of a completely randomized block in a factorial arrangement $3 \times 4$ with four replicates. Three types of ash (bagasse, bagasse+PJ07-A and bagasse+PJ07-RA) in four application rates $(0,5,15$ and 30 ton ha ${ }^{-1}$ ) were mixed into the soil, comprising a total of 12 treatments. Each plot consisted of 5 lines of rice with $3 \mathrm{~m}$ in length spaced by $0.4 \mathrm{~m}$, resulting in a total area of $6 \mathrm{~m}^{2}$. 
To obtain the ash "bagasse", sugarcane bagasse was burned alone and the ash was collected at the room of ashes. In order to obtain bagasse+PJ07-A and bagasse+PJ07-RA, sugarcane bagasse were mixed with PJ07 (85\% of bagasse and $15 \%$ of PJ07), and ashes were collected in the ashtray (bagasse+PJ07-A) and room of ashes (bagasse+PJ07-RA), respectively, since in the ashtray remains bones and other heavy materials while fine particles of ash are deposited only in the room of ashes. The PJ07 is a mixture of bovine subproducts, such as fat, bone and blood, produced by Recycling Industry of Animal subproducts Mato Grosso LTDA. All ash types were analyzed before application and its chemical characteristics are presented in table 3 . These analyses showed that all source of ashes were partially burned, since they show high content of organic matter (TAB. 3).

To determine the effects of both, source and application rate of ash on soil chemical properties, soil samples were collected on 18 March 2008 (132 days after ashes mixing). For soil chemical analysis, five samples were collected from each plot at $0-20 \mathrm{~cm}$ soil depth and a composite sample was made. Soil samples were placed over paper towels at room temperature to dry and then milled. It were analyzed the soil $\mathrm{pH}$ and the contents of $\mathrm{P}, \mathrm{K}^{+}, \mathrm{Ca}^{2+}, \mathrm{Mg}^{2+}, \mathrm{Cu}^{2+}, \mathrm{Zn}^{2+}, \mathrm{Fe}^{3+}$, $\mathrm{Mn}^{2+}, \mathrm{H}^{+}+\mathrm{Al}^{3+}$ and organic carbon. The $\mathrm{pH}$ was determined in water. Available $\mathrm{P}$ and $\mathrm{K}$ were extracted with Mehlich1 solution $\left(\mathrm{HCl} ; 0,5 \mathrm{~N}+\mathrm{H}_{2} \mathrm{SO}_{4} ; 0,025 \mathrm{~N}\right)$ and determined with a colorimeter and flame photometer, respectively. For $\mathrm{Ca}^{2+}$ and $\mathrm{Mg}^{2+}$ it was used $1 \mathrm{M} \mathrm{KCl}$ as extractor and determined by EDTA titration. Contents of $\mathrm{Cu}, \mathrm{Zn}, \mathrm{Fe}$ and $\mathrm{Mn}$ were determined by atomic absorption spectrophotometry using Mehlich1 as extractor. The $\mathrm{H}^{+}+\mathrm{Al}^{3+}$ contents were determined by titration, using $\mathrm{Ca}\left(\mathrm{CH}_{3} \mathrm{COO}\right)_{2} \cdot \mathrm{H}_{2} \mathrm{O}$ solution $(1 \mathrm{~N} ; \mathrm{pH} 7)$ for their extraction. Organic carbon was determined by Walkley \& Black method (EMBRAPA, 1997). The cation exchange capacity (CEC); base saturation; and $\mathrm{Ca}, \mathrm{Mg}$ and $\mathrm{K}$ saturations were calculated according to Fageria et al. (2007).

Effects of source ash were determined by analysis of variance according to the mathematical model corresponding to completely randomized block

Table 1 - Chemical and physical properties of the soil at $20 \mathrm{~cm}$ depth before ash application

\begin{tabular}{|c|c|c|c|c|c|c|c|}
\hline $\mathrm{pH}$ & $\mathrm{Ca}$ & $\mathrm{Mg}$ & $\mathrm{Al}$ & $\mathrm{H}+\mathrm{Al}$ & $\mathrm{P}$ & & $\mathrm{K}$ \\
\hline in $\mathrm{H}_{2} \mathrm{O}$ & \multicolumn{4}{|c|}{ 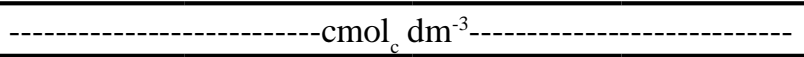 } & \multicolumn{3}{|c|}{----------------'mg dm ${ }^{-3}$} \\
\hline 6.45 & 3.74 & 1.33 & 0 & 3.82 & 33.78 & & 203.00 \\
\hline $\mathrm{Cu}$ & $\mathrm{Zn}$ & $\mathrm{Fe}$ & $\mathrm{Mn}$ & $\mathrm{C}_{\mathrm{org}}$ & Clay & Silt & Sand \\
\hline \multicolumn{4}{|c|}{$\mathrm{mg} \mathrm{dm}{ }^{-3}$} & $\%$ & \multicolumn{3}{|c|}{$\mathrm{g} \mathrm{kg}^{-1}$} \\
\hline 2.38 & 7.05 & 23.25 & 67.00 & 3.79 & 485 & 170 & 345 \\
\hline
\end{tabular}

Table 2 - Values of some climate components during entire experimental period

\begin{tabular}{lcccccc}
\hline & \multicolumn{2}{c}{ Mean temperature $\left({ }^{\circ} \mathrm{C}\right)$} & Mean humidity & Total precipitation & Total evapotraspiration & Solar radiation \\
\hline & Maximum & Minimum & $(\%)$ & $(\mathrm{mm})$ & $(\mathrm{mm})$ & $\left.(\mathrm{h} \mathrm{day})^{-1}\right)$ \\
\hline Nov 2007 & 30.8 & 19.7 & 77 & 171.5 & 126.0 & 6.2 \\
Dec 2007 & 29.4 & 19.5 & 82 & 207.3 & 114.3 & 5.3 \\
Jan 2008 & 28.6 & 19.4 & 85 & 347.8 & 161.6 & 5.0 \\
Feb 2008 & 29.1 & 19.4 & 87 & 292.3 & 127.9 & 4.5 \\
\hline
\end{tabular}

Source: Meteorological station of the Embrapa Rice and Beans, County of Santo Antônio de Goiás, Goiás, Brazil

Table 3 - Chemical characteristics of the ashes

\begin{tabular}{cccrrrrr}
\hline \multirow{2}{*}{ Source of ash } & \multirow{2}{*}{$\mathrm{pH}_{\text {in } \mathrm{H}_{2} \mathrm{O}}$} & \multicolumn{1}{c}{$\mathrm{P}$} & $\mathrm{K}$ & $\mathrm{Ca}$ & $\mathrm{Mg}$ & $\mathrm{O} . \mathrm{M}$ & Other minerals \\
\cline { 3 - 8 } & & & & & $\mathrm{g} \mathrm{kg}^{-1}$ & & \\
\hline Bagasse & 9.25 & 21.41 & 14.94 & 36.46 & 3.01 & 120 & 170 \\
Bagasse+PJ07-A & 9.06 & 90.46 & 3.32 & 155.87 & 3.01 & 40 & 800 \\
Bagasse+PJ07-RA & 8.86 & 61.18 & 8.30 & 86.51 & 3.01 & 70 & 360 \\
\hline
\end{tabular}

Bagasse: Sugarcane bagasse burned alone and collected at the room of ashes; Bagasse+PJ07-A: Sugarcane bagasse mixed with PJ07 and collected in the ashtray; Bagasse+PJ07-RA: Sugarcane bagasse mixed with PJ07 and collected in the room of ashes; PJ07: Mix of bovine sub-products; O. M: Organic matter 
design in a factorial arrangement. Mean of treatments were compared by Tukey test at $5 \%$ level and, rates ash effect were determined by regression analysis.

\section{Results and discussion}

The analysis of variance showed that some soil chemical properties such as $\mathrm{pH}$ and the content of $\mathrm{P}$ and $\mathrm{K}$ were significantly affected by the source of ash (TAB. 4). These findings corroborates with Demeyer et al. (2001) which attibuted the increase of soil $\mathrm{pH}$ and decrease of exchangeable Al contents of acid soils to the high alkalinity of the ashes, or the increase in the soil solution $\mathrm{pH}$ was partly due to ligand exchange between ash $\mathrm{SO}_{4}$ and $\mathrm{OH}^{-}$ions (NKANA et al., 2002). However, in many cases, changes in $\mathrm{pH}$ values are strongly dependent of ash rates application (MATSI; KERAMIDAS, 1999), as observed on Table 4. These are very important finding because in Brazilian Oxisols, high productivities of most annual crops such as dry bean, soybean and corn can be achieved at pH around 6.5 (FAGERIA et al., 2007), which can be reached by using the sources and rates of ash evaluated in this study (TAB. 4).

Table 4 - Influence across source and rate of ash on some soil chemical properties at 132 days after application

\begin{tabular}{|c|c|c|c|c|c|c|}
\hline \multirow{2}{*}{ Treatments } & \multirow{2}{*}{$\mathrm{pH}$ in $\mathrm{H}_{2} \mathrm{O}$} & & $\mathrm{Ca}$ & $\mathrm{Mg}$ & $\mathrm{H}+\mathrm{Al}$ & $\mathrm{P}$ \\
\hline & & \multicolumn{4}{|c|}{$\mathrm{cmol}_{\mathrm{c}} \mathrm{dm}^{-3}$} & $\mathrm{mg} \mathrm{dm}{ }^{-3}$ \\
\hline \multicolumn{7}{|l|}{ Source of ash (SA) } \\
\hline Bagasse & $6.59 \mathrm{~b}$ & & 3.64 & 1.24 & 3.55 & $135.97 \mathrm{~b}$ \\
\hline Bagasse+PJ07-A & $6.61 \mathrm{~b}$ & & 3.74 & 1.24 & 3.48 & $154.65 \mathrm{~b}$ \\
\hline Bagasse+PJ07-RA & $6.81 \mathrm{a}$ & & 3.73 & 1.27 & 3.30 & $401.83 \mathrm{a}$ \\
\hline \multicolumn{7}{|l|}{ Rate $(\mathrm{R})$} \\
\hline 0 & $6.37 \mathrm{c}$ & & 3.42 & $1.12 \mathrm{~b}$ & $3.99 \mathrm{a}$ & $14.83 \mathrm{~b}$ \\
\hline 5 & $6.54 \mathrm{~b}$ & & 3.61 & $1.20 \mathrm{~b}$ & $3.65 \mathrm{a}$ & $104.70 \mathrm{ab}$ \\
\hline 15 & $6.70 \mathrm{~b}$ & & 3.74 & $1.30 \mathrm{a}$ & $3.42 \mathrm{a}$ & $340.19 \mathrm{a}$ \\
\hline 30 & $7.08 \mathrm{a}$ & & 4.06 & $1.38 \mathrm{a}$ & $2.71 \mathrm{~b}$ & $463.54 \mathrm{a}$ \\
\hline \multicolumn{7}{|l|}{ F-test } \\
\hline $\mathrm{SA} \times \mathrm{R}$ & $*$ & & ns & $*$ & $*$ & $* *$ \\
\hline $\mathrm{CV}(\%)$ & 4.09 & & 17.22 & 12.71 & 21.99 & 37.77 \\
\hline \multirow[t]{2}{*}{ Treatments } & $\mathrm{K}$ & $\mathrm{Cu}$ & $\mathrm{Zn}$ & $\mathrm{Fe}$ & $\mathrm{Mn}$ & $\mathrm{C}_{\mathrm{org}}$ \\
\hline & & & $\mathrm{mg} \mathrm{dm^{-3 }}$ & & & $\%$ \\
\hline \multicolumn{7}{|l|}{ Source of ash (SA) } \\
\hline Bagasse & $163.13 \mathrm{a}$ & 2.24 & 5.09 & 26.69 & 61.31 & 3.57 \\
\hline Bagasse+PJ07-A & $111.69 \mathrm{~b}$ & 2.26 & 5.44 & 28.94 & 60.75 & 3.44 \\
\hline Bagasse+PJ07-RA & $159.69 \mathrm{a}$ & 2.14 & 4.13 & 25.00 & 59.63 & 3.58 \\
\hline \multicolumn{7}{|l|}{ Rate (R) } \\
\hline 0 & $111.75 \mathrm{~b}$ & $2.44 \mathrm{a}$ & 4.52 & 28.58 & 58.58 & 3.52 \\
\hline 5 & $105.42 \mathrm{~b}$ & $2.19 \mathrm{~b}$ & 5.39 & 27.25 & 60.17 & 3.36 \\
\hline 15 & $144.08 \mathrm{~b}$ & $2.14 \mathrm{~b}$ & 4.41 & 25.83 & 59.83 & 3.59 \\
\hline 30 & $206.08 \mathrm{a}$ & $2.08 \mathrm{~b}$ & 5.22 & 25.83 & 63.67 & 3.46 \\
\hline \multicolumn{7}{|l|}{ F-test } \\
\hline $\mathrm{SA} \times \mathrm{R}$ & $*$ & ns & ns & ns & ns & ns \\
\hline $\mathrm{CV}(\%)$ & 29.96 & 9.13 & 24.82 & 19.51 & 18.03 & 6.77 \\
\hline
\end{tabular}

Bagasse: Sugarcane bagasse burned alone and collected at the room of ashes; Bagasse+PJ07-A: Sugarcane bagasse mixed with PJ07 and collected in the ashtray; Bagasse+PJ07-RA: Sugarcane bagasse mixed with PJ07 and collected in the room of ashes; PJ07: Mix of bovine sub-products. Rate: expressed on $\mathrm{Mg} \mathrm{ha}^{-1}$.**,* and ns: interaction significance by F-test at $\mathrm{p}<0.01, \mathrm{p}<0.05$ and non significant, respectively. $\mathrm{C}_{\text {org }}$ : Organic carbon. Means in the same column followed by the same or none letter are not different by the Tukey test $(\mathrm{p}<0.05)$ 
Phosphorus and K levels were significantly increased with sources and rates of ashes, as well as its interaction (TAB. 4). The P contents of the soil was more pronounced affected by the addition of Bagasse+PJ07-RA, in which the highest value found was about $400 \mathrm{mg} \mathrm{dm}^{-3}$ (TAB. 4), while for $\mathrm{K}$ contents significant effect was observed for the use of Bagasse and Bagasse+PJ07-A.

These results indicate that the $\mathrm{P}$ and $\mathrm{K}$ contents are enough to provide the maximum economic yield of annual crops, since for Cerrado Oxisols was stated that levels of $\mathrm{P}$ around $10-15 \mathrm{mg} \mathrm{kg}^{-1}$ by the Mehlich 1 extracting solution and of $\mathrm{K}$ higher than $50 \mathrm{mg} \mathrm{kg}^{-1}$ can promote good yields for the most annual crops in these soils (FAGERIA, 1992). Besides, the application of fertilizers for soybean, corn and common bean in the established no-tillage system and with high $\mathrm{P}$ content and medium $\mathrm{K}$ content can be performed independent of the localization (furrow or total area) and period (winter and summer). Even with medium $\mathrm{K}$ content, there is no need to apply fertilizers in the sowing furrow, not even the presence of this nutrient in the furrow interferes negatively on the yields of corn, common bean and soybean (PAULETTI et al., 2010).

Levels of micronutrients $(\mathrm{Cu}, \mathrm{Zn}, \mathrm{Fe}, \mathrm{Mn})$ and $\mathrm{C}_{\text {org }}$ were not influenced by ash sources and rates (TAB. 4); however, according to Fageria et al. (1997) the contents found on the different sources and rate of ashes are sufficient for adequate growth and development of annual crops.
Although no changes were observed on $\mathrm{Ca}$ and Mg contents (TAB. 4), some studies have shown effect of ash application on soil macroelements. According to Mandre et al. (2006a), Mg concentration were very small at the beginning of the experiments, but an increase in the $\mathrm{Mg}$ concentration in soil was established one year after the treatment. They also related that the increase of Klason lignin as a result of ash application correlated negatively with $\mathrm{N}$ and positively with $\mathrm{K}, \mathrm{Mg}$ and $\mathrm{Ca}$ in soil. Besides, large increases in concentrations of inorganic $\mathrm{Ca}$ and $\mathrm{Mg}$ with ash relative to lime and especially increases in $\mathrm{K}$ reflected the supply of these elements by ash (NKANA et al., 2002).

The same soil chemical properties affected by the source of ash were also influenced by ash rate. In addition, ash rate also significantly changed the contents of $\mathrm{Mg}, \mathrm{H}+\mathrm{Al}$ and $\mathrm{Cu}$ in the soil (TAB. 4), in way that the greater rates of ash promoted a general improve on the soil chemical properties. Our findings are supported by the results of Mandre (2006a), which reported a strong relationship among ash rate and some soil nutrients.

Source of ash only affected K Sat; however, BS, $\mathrm{Ca}$ Sat, Mg Sat and K Sat were influenced by the rates of ash at 5\% (TAB. 5). Since ashes are composed by alkaline elements (MANDRE et al., 2006b), on a shortterm the increase of its rate may change the balance of these elements on the soil solution.

Table 5 - Influence across source of ash application on cation exchange capacity (CEC), base saturation (BS), Al saturation (AL Sat), Ca saturation (Ca Sat), Mg saturation (Mg Sat) and K saturation (K Sat) at 132 days after ash application

\begin{tabular}{|c|c|c|c|c|c|}
\hline \multirow{2}{*}{ Treatments } & $\mathrm{CEC}$ & $\mathrm{BS}$ & $\mathrm{Ca}$ Sat & Mg Sat & K Sat \\
\hline & $\left(\mathrm{cmol} \mathrm{kg}^{-1}\right)$ & \multicolumn{4}{|c|}{$(\%)$} \\
\hline \multicolumn{6}{|l|}{ Source of ash (SA) } \\
\hline Bagasse & 8.85 & 59.79 & 41.01 & 14.04 & $4.74 \mathrm{a}$ \\
\hline Bagasse+PJ07-A & 8.75 & 60.34 & 42.85 & 14.19 & $3.30 \mathrm{~b}$ \\
\hline Bagasse+PJ07-RA & 8.69 & 61.98 & 42.92 & 14.62 & $4.44 \mathrm{a}$ \\
\hline \multicolumn{6}{|l|}{ Rate (R) } \\
\hline 0 & 8.82 & $54.83 \mathrm{~b}$ & $38.82 \mathrm{~b}$ & $12.74 \mathrm{~b}$ & $3.27 \mathrm{~b}$ \\
\hline 5 & 8.72 & $58.21 \mathrm{~b}$ & $41.38 \mathrm{~b}$ & $13.73 b$ & $3.10 \mathrm{~b}$ \\
\hline 15 & 8.84 & $61.13 \mathrm{~b}$ & $42.22 \mathrm{~b}$ & $14.72 \mathrm{a}$ & $4.18 \mathrm{~b}$ \\
\hline 30 & 8.67 & $68.65 \mathrm{a}$ & $46.63 \mathrm{a}$ & $15.94 \mathrm{a}$ & $6.08 \mathrm{a}$ \\
\hline \multicolumn{6}{|l|}{ F-test } \\
\hline SA $x \mathrm{R}$ & ns & $*$ & ns & $*$ & $*$ \\
\hline $\mathrm{CV}(\%)$ & 5.98 & 13.5 & 14.81 & 12.52 & 29.82 \\
\hline
\end{tabular}

Bagasse: Sugarcane bagasse burned alone and collected at the room of ashes; Bagasse+PJ07-A: Sugarcane bagasse mixed with PJ07 and collected in the ashtray; Bagasse+PJ07-RA: Sugarcane bagasse mixed with PJ07 and collected in the room of ashes; PJ07: Mix of bovine sub-products. Rate: expressed on Mg ha ${ }^{-1}$ * and ns: significant and non significant, respectively, interaction by F-test ( $\mathrm{p}<0.05$ ). Ca sat, $\mathrm{Mg}$ sat and $\mathrm{K}$ sat $=\mathrm{Ca}, \mathrm{Mg}$ and $\mathrm{K}$ saturation, respectively. $*$ significant at the ( $\mathrm{p}<0.05)$; ns- non significant. Means in the same column followed by the same or none letter are not different by the Tukey test $(\mathrm{p}<0.05)$ 
In comparison with the control $\left(0 \mathrm{Mg} \mathrm{ha}^{-1}\right)$, the highest ash rate $\left(30 \mathrm{Mg} \mathrm{ha}^{-1}\right)$ promoted an increase of $25 \% ; 20 \% ; 25 \%$ and $86 \%$ on BS, Ca Sat, Mg Sat and K Sat, respectively, which corroborate with the results found by Im-Erb et al. (2004). The critical values for $\mathrm{Ca}$ and $\mathrm{Mg}$ saturation percentages, which are used as an indicator of calcium and magnesium deficiency for most plants, are 25-30 and 5\% respectively (ADAMS, 1984; KAMPRATH, 1984). Both calcium and magnesium levels in this study were found to be close or higher than the critical values.

Significant interactions were observed among source of ash and rate (SA x R) for $\mathrm{pH}, \mathrm{Mg}, \mathrm{H}+\mathrm{Al}, \mathrm{P}, \mathrm{K}, \mathrm{BS}, \mathrm{Mg}$ sat and $\mathrm{K}$ sat, while the other soil chemical properties did not show significant interaction (TAB. 4 and 5). Ash application as soil amendment is principally used to improve the chemical properties of the soil because of its high alkalinity and elevated contents in alkaline earth elements (MANDRE, 2006a). Ashes are therefore excellent amendments for tropical acid soils to reduce $\mathrm{Al}$ and Mn toxicity. Considering its chemical composition, ash constitutes an excellent source of major and minor nutrient elements and is therefore of interest in correcting certain nutrient deficiencies in soils (DEMEYER et al., 2001). Significant interactions found in our work were analyzed and mean comparisons are given on TAB. 6.

Table 6 - Influence of type and rate interaction on soil chemical properties at 132 days after ash application

\begin{tabular}{|c|c|c|c|c|c|}
\hline \multirow{2}{*}{ Source of aAsh } & \multirow{2}{*}{ Rate $\mathrm{Mg} \mathrm{ha}^{-1}$} & \multirow{2}{*}{$\mathrm{pH}$ in $\mathrm{H}_{2} \mathrm{O}$} & $\mathrm{Mg}$ & $\mathrm{H}+\mathrm{Al}$ & \multirow{2}{*}{$\frac{\mathrm{P}}{\mathrm{mg} \mathrm{dm}}$} \\
\hline & & & \multicolumn{2}{|c|}{$\mathrm{cmol}_{\mathrm{c}} \mathrm{dm}^{-3}$} & \\
\hline \multirow{4}{*}{ Bagasse } & 0 & $6.20 \mathrm{~b}$ & 1.09 & $4.34 \mathrm{a}$ & $5.83 \mathrm{~b}$ \\
\hline & 5 & $6.58 \mathrm{~b}$ & 1.23 & $3.61 \mathrm{a}$ & $10.65 \mathrm{~b}$ \\
\hline & 15 & $6.40 \mathrm{~b}$ & 1.23 & $3.72 \mathrm{a}$ & $17.15 \mathrm{~b}$ \\
\hline & 30 & $7.18 \mathrm{a}$ & 1.43 & $2.48 \mathrm{~b}$ & $510.20 \mathrm{a}$ \\
\hline \multirow{4}{*}{ Bagasse+PJ07-A } & 0 & $6.43 \mathrm{~b}$ & $1.12 \mathrm{~b}$ & $3.85 \mathrm{a}$ & $30.25 \mathrm{~b}$ \\
\hline & 5 & $6.35 \mathrm{~b}$ & $1.15 \mathrm{~b}$ & $3.90 \mathrm{a}$ & $51.90 \mathrm{~b}$ \\
\hline & 15 & $6.63 \mathrm{~b}$ & $1.22 \mathrm{~b}$ & $3.57 \mathrm{a}$ & $149.45 \mathrm{~b}$ \\
\hline & 30 & $7.08 \mathrm{a}$ & $1.46 \mathrm{a}$ & $2.61 \mathrm{~b}$ & $387.00 \mathrm{a}$ \\
\hline \multirow{4}{*}{ Bagasse+PJ07-RA } & 0 & $6.48 \mathrm{~b}$ & 1.16 & 3.79 & $8.37 \mathrm{c}$ \\
\hline & 5 & $6.70 \mathrm{~b}$ & 1.21 & 3.44 & $251.55 \mathrm{~b}$ \\
\hline & 15 & $7.08 \mathrm{a}$ & 1.46 & 3.04 & $853.98 \mathrm{a}$ \\
\hline & 30 & $6.98 \mathrm{a}$ & 1.26 & 2.94 & $483.43 \mathrm{~b}$ \\
\hline $\mathrm{CV}(\%)$ & & 4.09 & 12.71 & 21.99 & 37.77 \\
\hline \multirow{2}{*}{ Source of aAsh } & \multirow{2}{*}{ Rate $\mathrm{Mg} \mathrm{ha}^{-1}$} & $\mathrm{~K}$ & $\mathrm{BS}$ & Mg sat & K sat \\
\hline & & $\mathrm{mg} \mathrm{dm}^{-3}$ & \multicolumn{3}{|c|}{$(\%)$} \\
\hline \multirow{4}{*}{ Bagasse } & 0 & $113.00 \mathrm{~b}$ & $51.32 \mathrm{~b}$ & $12.30 \mathrm{~b}$ & $3.30 \mathrm{~b}$ \\
\hline & 5 & $126.25 \mathrm{~b}$ & $58.98 \mathrm{~b}$ & $13.99 \mathrm{~b}$ & $3.69 \mathrm{~b}$ \\
\hline & 15 & $132.50 \mathrm{~b}$ & $57.15 \mathrm{~b}$ & $13.68 \mathrm{~b}$ & $3.80 \mathrm{~b}$ \\
\hline & 30 & $280.75 \mathrm{a}$ & $71.72 \mathrm{a}$ & $16.20 \mathrm{a}$ & $8.17 \mathrm{a}$ \\
\hline \multirow{4}{*}{ Bagasse+PJ07-A } & 0 & $92.00 \mathrm{~b}$ & $56.45 \mathrm{~b}$ & $12.69 \mathrm{~b}$ & $2.70 \mathrm{~b}$ \\
\hline & 5 & $85.75 \mathrm{~b}$ & $55.75 \mathrm{~b}$ & $13.10 \mathrm{~b}$ & $2.47 \mathrm{~b}$ \\
\hline & 15 & $105.00 \mathrm{~b}$ & $59.04 \mathrm{~b}$ & $14.22 \mathrm{~b}$ & $3.20 \mathrm{~b}$ \\
\hline & 30 & $164.00 \mathrm{a}$ & $70.13 \mathrm{a}$ & $16.76 \mathrm{a}$ & $4.82 \mathrm{a}$ \\
\hline \multirow{4}{*}{ Bagasse+PJ07-RA } & 0 & $130.25 \mathrm{~b}$ & 56.73 & 13.24 & $3.82 \mathrm{~b}$ \\
\hline & 5 & $104.25 \mathrm{~b}$ & 59.91 & 14.11 & $3.13 \mathrm{~b}$ \\
\hline & 15 & $194.75 \mathrm{a}$ & 67.20 & 16.27 & $5.56 \mathrm{a}$ \\
\hline & 30 & $173.50 \mathrm{a}$ & 64.09 & 14.87 & $5.24 \mathrm{a}$ \\
\hline $\mathrm{CV}(\%)$ & & 29.96 & 13.50 & 12.52 & 29.82 \\
\hline
\end{tabular}

Ca sat, $\mathrm{Mg}$ sat and $\mathrm{K}$ sat $=\mathrm{Ca}, \mathrm{Mg}$ and $\mathrm{K}$ saturation, respectively 
For all sources of ash and considering the evaluated soil chemical properties, the best results were mainly achieved at the highest ash rate $\left(30 \mathrm{Mg} \mathrm{ha}^{-1}\right)$. The effect of ash rates within all ash types, indicates that ash rate influence on soil chemical properties is determined by its source. In all the three sources of ash, soil $\mathrm{pH}$ was significantly higher at $30 \mathrm{Mg} \mathrm{ha}^{-1}$ treatment compared to lower rates of ash, except Bagasse+PJ07-RA. Soil pH increased from 6.20 to 7.18 by increasing bagasse rate, 6.43 to 7.08 by increasing bagasse+PJ07-A rate, and 6.48 to 6.98 by increasing bagasse+PJ07-RA rate (TAB 6).

Regression analysis revealed the influence of ash rates on soil chemical properties as presented in FIG. 1. There were significant changes in soil $\mathrm{pH}$ and contents of $\mathrm{Mg}, \mathrm{H}+\mathrm{Al}, \mathrm{P}$ and $\mathrm{K}$ with the application of four rates of ash. Increasing rates of ash in the range of 0 to $30 \mathrm{Mg} \mathrm{ha}^{-1}$ increased soil $\mathrm{pH}$ linearly with determination coefficient around $98 \%$. Similarly values of $\mathrm{Mg}, \mathrm{P}$ and $\mathrm{K}$ were increased significantly in a linear model with increasing ash rates. Similarly, the contents of $\mathrm{P}, \mathrm{K}$ and $\mathrm{Mg}$ increased in the soil as a result of the increasing of the ash rates, showing determination coefficients of $91.81 \%, 92.11 \%$ and $92.56 \%$, respectively. On the other hand, $\mathrm{H}+\mathrm{Al}$ content decreased significantly in a linear model with increasing ash rate (FIG. 1). However, soil contents of $\mathrm{Ca}, \mathrm{Cu}, \mathrm{Zn}, \mathrm{Fe}, \mathrm{Mn}$ and $\mathrm{C}_{\text {org }}$ were not affected by ash treatments (TAB. 4). These results corroborates some works wich had reported similar effects of ash on soil chemical properties at rates varying from $5 \mathrm{Mg} \mathrm{ha}^{-1}$ (MATERECHERA; MKHABELA, 2002) to $120 \mathrm{Mg} \mathrm{ha}^{-1}$ (LEE et al., 2006).

The increase in $\mathrm{Mg}$ content in the soil was significantly influenced by Bagasse $\mathrm{x}$ rate interaction (TAB. 4). Values of $\mathrm{Mg}$ varied from 1.09 to 1.43 under bagasse treatment, 1.12 to 1.46 under bagasse+PJ07-A treatment and 1.16 to 1.26 under bagasse+PJ07-RA treatment. The average values of $\mathrm{Mg}$ across sources (TAB. 6) and rates (FIG. 1) were 1.24 to 1.27 and 1.12 to $1.38 \mathrm{cmol}_{\mathrm{c}} \mathrm{kg}^{-1}$, respectively. According to Fageria and Baligar (2001), most of the annual crops can produce well under $\mathrm{Mg}$ level higher than $1 \mathrm{cmol}_{\mathrm{c}} \mathrm{kg}^{-1}$, which means that under the studied conditions even at the lowest applied ash rate ( $5 \mathrm{Mg} \mathrm{ha}^{-1}$ ) is sufficient to provide an adequate content of $\mathrm{Mg}$ in Cerrado Oxisols for annual crops.

Ash source promoted significant differences for $\mathrm{K}$ saturation in which smallest values of $\mathrm{K}$ saturation was observed for Bagasse+PJ07-A. This result can be related with the chemical characteristics of the ashes, since Bagasse+PJ07-A showed the smallest content of $\mathrm{K}$ among ash types (TAB. 3) thus, each type of ash showed distinct capacity to provide $\mathrm{K}$ to soil solution, corroborating the findings of Nkana et al. (2002).
Figure 1 - Regression analysis of ash rate effects on $\mathrm{pH}(\mathrm{A})$ and soil concentration of $\mathrm{H}+\mathrm{Al}, \mathrm{Mg}(\mathrm{B}), \mathrm{P}$ and $\mathrm{K}(\mathrm{C})$
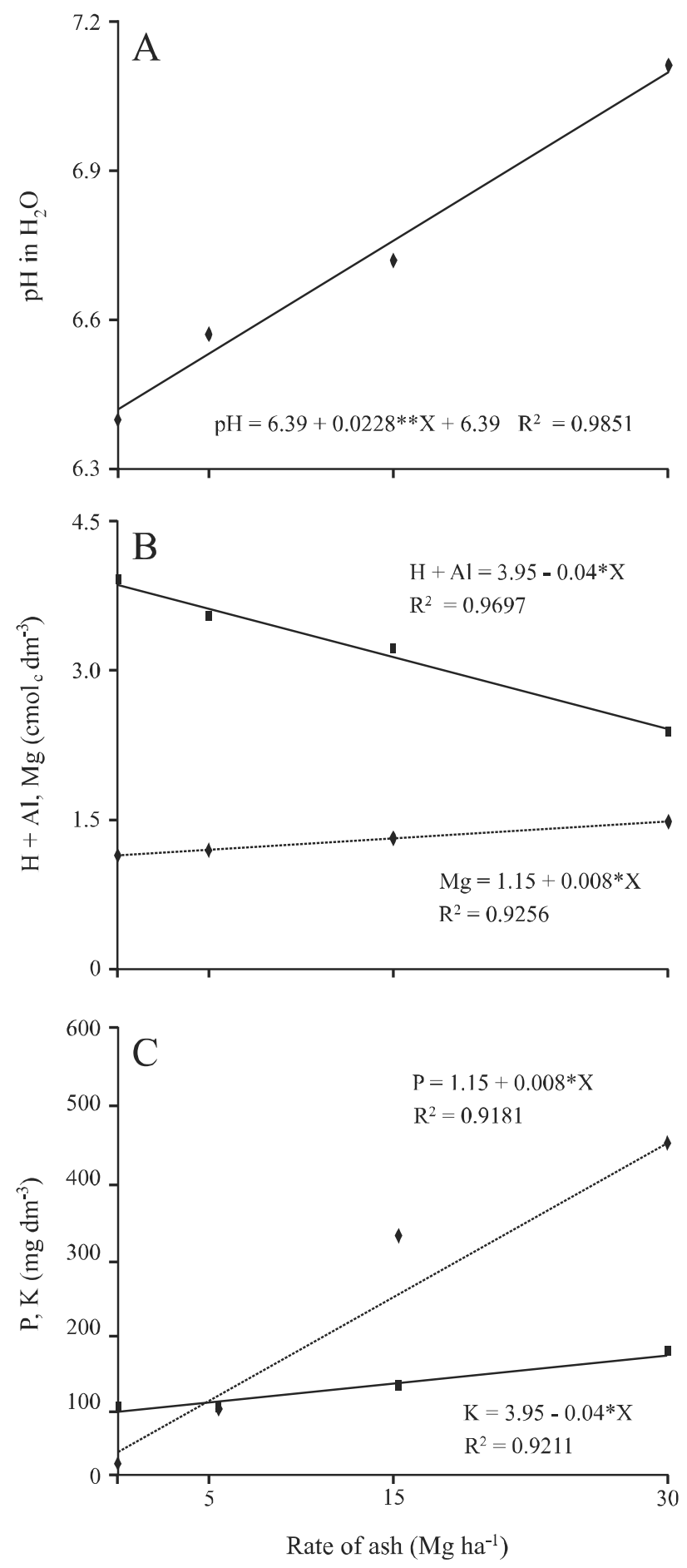

Although the literature reports effect of ash application on cation exchange capacity and base saturation (ARVIDSSON; LUNDKVIST, 2003; WEBER- 
BLASCHKE et al., 2002) these parameters were not influenced by ash source in this study (TAB. 5).

However, influence of ash rates were observed for base saturation, $\mathrm{Ca}$ saturation, $\mathrm{Mg}$ saturation and $\mathrm{K}$ saturation (TAB. 5), hence greater rates resulted in an increasing on the values of these soil properties (FIG. 2).

Base saturation, $\mathrm{Ca}, \mathrm{K}$ and $\mathrm{Mg}$ saturation significantly increased with the addition of ash in the range of 0 to $30 \mathrm{Mg} \mathrm{ha}^{-1}$ (FIG. 2). In Brazilian Oxisols the adequate level of base saturation, $\mathrm{Ca}$ saturation, $\mathrm{Mg}$ saturation and $\mathrm{K}$ saturation is around 60, 40, 15 and 4\%, respectively (FAGERIA; BALIGAR, 2001; FAGERIA; STONE, 2004). This means that, under our study conditions, any source of ash at $5 \mathrm{Mg} \mathrm{ha}^{-1}$ provide saturation conditions of nutrients sufficient for the growth of of most annual crops like dry bean, soybean and corn. However, as there was no effect of ash source in some of the studied parameters, economic studies should be done to assess the feasibility of using these ashes, especially those to which the product PJ07 was incorporated.

Figure 2 - Regression analysis of ash rate effects on base saturation (BS), Ca saturation (Ca Sat), Mg saturation (Mg Sat) and $\mathrm{K}$ saturation (K Sat)

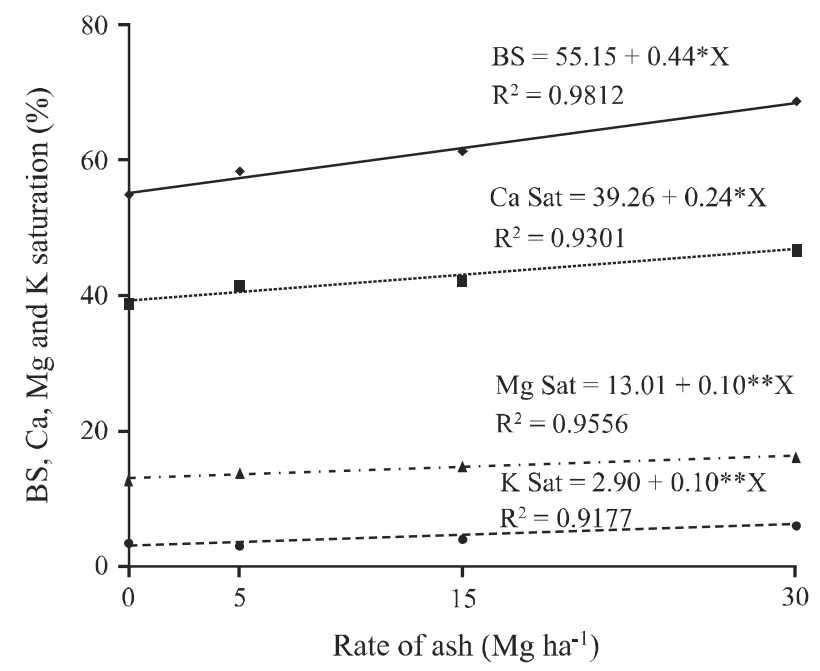

\section{Conclusion}

Under our study condition we can conclude that depending on the ash source or rate, some of the soil chemical properties are affected, however, the effect of ash source is not so pronounced as compared with ash rate. Ash application led the soil nutritional status to a level enough to guarantee nutritional conditions for the growth and yield of most annual crops. The three ash sources (bagasse, bagasse+PJ07, and
bagasse+PJ07-RA) were equally effective in reducing acidity and improving soil fertility under this study condition, while increasing ash rate provides decrease in $\mathrm{H}+\mathrm{Al}$ content and increase in $\mathrm{pH}, \mathrm{Mg}, \mathrm{P}$ and $\mathrm{K}$.

\section{Acknowledgments}

Authors would like to thanks to the agreement INCRA/FAPED/EMBRAPA for the financial support and to Mr. Pedro Daniel Bittar for providing the ash materials used in this experiment.

\section{References}

ADAMS, F. Crop Response to Lime in the Southern United States. In: ADAMS, F. Soil Acidity and Liming, 1984. p. 211-265. (Agronomy Monograph, 12).

ADRIANO, D. C. et al. Utilization and disposal of fly ash and other coal residues in terrestrial ecosystem. A review. Journal of Environmental Quality, v. 09, n. 03, p. 333-334, 1980.

ALONSO-PIPPO, W. et al. Sugarcane energy use: The Cuban case. Energy Policy, v. 36, n. 06, p. 2163-2181, 2008.

ARVIDSSON, H.; LUNDKVIST, H. Effects of crushed wood ash on soil chemistry in young Norway spruce stands. Forest Ecology and Management, v. 176, n. 01/03, p. 121-132, 2003.

DEMEYER, A.; NKANA, J. C. V.; VERLOO, M. G. Characteristics of wood ash and influence on soil properties and nutrient uptake: an overview. Bioresource Technology, v. 77, n. 03, p. 287-295, 2001.

DORAN, J. W. Soil health and global sustainability: translating science into practice. Agriculture, Ecosystems and Environment, v. 88, n. 02, p. 119-127, 2002.

EMPRESA BRASILEIRADE PESQUISAAGROPECUÁRIA (EMBRAPA). Manual for Methods of Soil Analysis. $2^{\text {nd }}$ ed. Rio de Janeiro: National Service for Soil Survey and Soil Conservation, 1997.

FAGERIA, N. K. Maximizing crop yields. New York: Marcel Dekker, 1992. 274 p.

FAGERIA, N. K.; BALIGAR, V. C. Improving nutrient use efficiency of annual crops in Brazilian acid soils for sustainable crop production. Communications in Soil Science and Plant Analysis, v. 32, n. 07/08, p. 1303-1319, 2001.

FAGERIA, N. K.; BALIGAR, V. C.; JONES, C. A. Growth and mineral nutrition of field crops, 2nd ed.New York: Marcel Dekker, 1997. $624 \mathrm{p}$.

FAGERIA, N. K.; BALIGAR, V. C.; ZOBEL, R. W. Yield, nutrient uptake, and soil chemical properties as influenced by liming and Boron application in common bean in a no-tillage system. Communications in Soil Science and Plant Analysis, v. 38, n. $11 / 12$, p. $1637-1653,2007$. 
FAGERIA, N. K.; STONE, L. F. Yield of common bean in no-tillage system with application of lime and zinc. Pesquisa Apropecuária Brasileira, v. 39, n. 39, p. 73-78, 2004.

FOOD AND AGRICULTURE ORGANIZATION OF THE UNITED NATIONS (FAO). Faostats. Available on < http:// faostat.fao.org/site/339/default.aspx >. Acessed on: 15 oct. 2010.GÓRECKA, H.; CHOJNACKA, K.; GÓRECKI, H. The application of ICP-MS and ICP-OES in determination of micronutrients in wood ashes used as soil conditioners. Talanta, v. 70, n. 05 , p. 950-956, 2006.

HASHIM, A. B.; AMINUDDIN, H.; SIVA, K. B. Nutrient content in rice husk ash of some Malaysian rice varieties, Pertaanika. Journal of Tropical Agricultural Science, v. 19, n. 01, p. 77-80, 1996.

IM-ERB, R. et al. Utilisation of coal ash to improve acid soil. Songklanakarin Journal of Science and Technology, v. 26, n. 05, p. 697-708, 2004.

KAMPRATH, E. J. Crop Response to Line on Soils in the tropics. In: ADAMS, F. Soil Acidity and Liming, p. 349-368, 1984. (Agronomy,12).

LEE, H. et al. Fly ash effect on improving soil properties and rice productivity in Korean paddy soils. Bioresouce Technology, v. 97, n. 13, p. 1490-1497, 2006.

MANDRE, M. Influence of wood ash on soil chemical composition and biochemical parameters of young Scots pine. Proceedings of the Estonian Academy of Sciences: Biology, Ecology, v. 55, n. 02, p. 91-107, 2006 .

MANDRE, M.; PÄRN, H.; OTS, K. Short-term effects of wood ash on the soil and lignin concentration and growth of Pinus sylvestris L. Forest Ecology and Management, v. 223, n. 01/03, p. 349-357, $2006 \mathrm{~b}$.

MATERECHERA, S. A.; MKHABELA, T. S. The effectiveness of lime, chicken manure and leaf litter ash in ameliorating acidity in a soil previously under black wattle (Acacia mearnsii) plantation. Bioresouce Technology, v. 85, n. 01, p. 9-16, 2002.

MATSI, T.; KERAMIDAS, V. Z. Fly ash application in two acid soils and its effect on soil salinity, $\mathrm{pH}, \mathrm{B}, \mathrm{P}$ and on ryegrass growth and composition. Environmental Pollution, v. 104, n. 01, p. 107-112, 1999.

MIRZA, U. K.; AHMAD, N.; MAJEED, T. An overview of biomass energy utilization in Pakistan. Renewable and Sustainable Energy Reviews, v. 12, n. 07, p. 1988-1996, 2008.
MOYIN-JESU, E. I. Use of plant residues for improving soil fertility, pod nutrients, root growth and pod weight of okra (Abelmoschus esculentum L.). Bioresouce Technology, v. 98, n. 11, p. 2057-206, 2007.

NKANA, J. C. V.; DEMEYER, A.; VERLOO, M. G. Effect of wood ash application on soil solution chemistry of tropical acid soils: incubation study. Bioresource Technology, v. 85, n. 03, p. 323-325, 2002.

OQUIST, K. A.; STROCK, J. S.; MULLA, D. J. Influence of alternative and conventional farming practices on subsurface drainage and water quality. Journal of Environmental Quality, v. 36, n. 04, p. 1194-1204, 2007.

PAULETTI, V. et al. Yield Response to Fertilization Strategies in No-Tillage Soybean, Corn and Common Bean Crops. Brazilian Archives of Biology and Technology, v. 53 n. 03, p. 563-574, 2010.

PERUCCI, P. et al. Changes in physico-chemical and biochemical parameters of soil following addition of wood ash:Afield experiment. European Journal of Agronomy, v. 28, n. 03, p. 155-161, 2008.

SAARSALMI, A. et al. Long-term effects of ash and N fertilization on stand growth, tree nutrient status and soil chemistry in a Scots pine stand. Forest Ecology and Management, v. 235, n. 01/03, p. 116-128, 2006.

SALEQUE, M. A. et al. Long-term effects of inorganic and organic fertilizers sources on yield and nutrient accumulation of lowland rice. Field and Crop Research, v. 86, n. 01, p. 53-65, 2004.

SELL, N. et al. The agronomic landspreading of coal bottom ash: using a regulated solid waste as a resource. Resources, Conservation and Recycling, v. 02, n. 02, p. 119-129, 1989.

SELMAN-HOUSEIN, G. et al. Towards the improvement of sugarcane bagasse as raw material for the production of paper pulp and animal feed. In: ARENCIBIA, A. D. (Ed.) Plant genetic engineering towards the third millenium. Elsevier, 2000. cap. 29, p.189-193.

SILVA, S. C. et al. Informações meteorológicas para pesquisa e planejamento agrícola referentes ao município de Santo Antônio de Goiás, GO. Santo Antônio de Goiás: Embrapa Arroz e Feijão, 2002. 21 p. (Documento, 136).

WEBER-BLASCHKE, G.; CLAUS, M.; REHFUESS, K. E. Growth and nutrition of ash (Fraximus excelsior L.) and sycamone (Acer pseudoplatanus L.) on soils of different base saturation in pot experiment. Forest Ecology and Management, v. 167, n. 01/03, p. 43-56, 2002. 